\title{
Rola Chilindaru w historii atoskiego monastycyzmu
}

\author{
ks. archimandryta Warsonofiusz Doroszkiewicz \\ Katedra Teologii Prawosławnej, Uniwersytet w Białymstoku \\ Polska \\ warsonofiusz@gmail.com
}

Rev. Warsonofiusz Doroszkiewicz, A Role of Chilendar in the history of athonite monasticism, Elpis, 17 2015: 53-58.

\begin{abstract}
The very destiny of Serbia has been connected with the athonite monastery Chilendar since thousand year. Monastery Chilendar since being accepted by the Serbian king had existed for 200 years before as a simple athonite monastery. However in 1198 it was officially given by the byzantine emperor Aleksios III Angelos to the Serbian king Stefan Nemania (his monastic name was Simeon) and his son duke Rastko who later became monk Sava. Those two saints of the Serbian Orthodox Church caused that monastery Chilendar had become the very center of the spiritual and cultural life of the Serbian state and political life during the osman slavery as well. Here in the climate of beautiful athonite nature, in the climate of prayer and in the shelter of the reach collection of libraries. Many of Serbian outstanding personalities received here spiritual and secular training needed for the mission and political work during years of the ottoman slavery. The very help coming from orthodox Russia and Romanian and Moldavian nobility, fathers of Chilendar sheared to the all athonite monasteries being in need regardless of ethnic descend of monks. Those little sums were directed to pay large taxes and renovations of monasteries that were in very bed state. After 500 period of the political-cultural and religious non-existence, Serbia paved the way for new European reality. Also the fate of the Chilendar had not remain neutral for the reconstructed new Serbian state. Once more monastery was filled up the serbian monks. That had rebuild the structures of the monastic life and created the very base for the further development of liberated from the Islamic slavery their Serbian country.
\end{abstract}

\begin{abstract}
Streszczenie: Los Serbii od tysiąca lat związany jest $\mathrm{z}$ atoskim monasterem Chilandar. Sam monaster do momentu przejęcia przez Serbów istniał już od dwustu lat jednakże w 1198 roku został oficjalnie przekazany przez cesarza bizantyńskiego Aleksego III Angelosa, serbskiemu królowi Stefanowi Nemanii (przyjął mnisze imię Symeon) oraz jego synowi Rastko, który przyjął na Atosie mnisze imię Sawa. Ci dwaj późniejsi święci Cerkwi serbskiej przeszedłszy na Atosie przez wszystkie stopnie życia monastycznego sprawili, że monaster Chilendar stał się centrum życia kulturowo - duchowego, jak również i politycznego czasach niewoli osmańskiej. To tutaj na tle przepięknej atoskiej przyrody w klimacie modlitwy i zaciszu bogatych zbiorów chilendarskiej biblioteki, najwybitniejsze autorytety zarówno duchowne jak i świeckie otrzymały przygotowanie dla pracy zarówno misyjnej jak i politycznej co było bardzo istotne w szczególności w czasach pięćset letniej niewoli tureckiej. Wszelką pomoc przychodzącą z zewnątrz, okupowanej Serbii jak również z prawosławnej Rosji i rumuńsko-mołdawskich możnowładców chilendarscy ojcowie dzielili pomiędzy wszystkie potrzebujące atoskie monastery nie bacząc na pochodzenie etniczne ich mnichów. Te małe sumy przeznaczane było do opłacania drakońskich podatków i renowacji podupadających atoskich monasterów. Po uzyskaniu niepodległości Serbia po okresie pięćsetletniego polityczno-kulturowo-religijnego niebytu musiała utorować sobie drogę do odnalezienia się w nowej europejskiej rzeczywistości. Również los Chilendaru nie pozostał obojętny dla formułującej się na od nowa serbskiej państwowości. Monaster zapełnił się na nowo serbskimi mnichami. Odbudowywali oni nie tylko struktury życia monastycznego ale kładli podwaliny dla dalszego duchowo-kulturalnego rozwoju wyzwolonej z islamskiej niewoli swojej serbskiej ojczyzny.
\end{abstract}

Keywords: Athos, Church, Serbia, monastery, St. Sava, monks

Słowa kluczowe: Atos, Cerkiew, Serbia, monaster, św. Sawa, mnisi

Kiedy w IX i X wieku w zachodniej części Rzymskiego Imperium, Kościół pod panowaniem Franków przeżywał głęboki kryzys, na Wschodzie monastycyzm pielęgnując ideę hezyhazmu doświadczał zadziwiającego rozkwitu. ${ }^{1} \mathrm{Od}$ samego początku pojawienia się monastycyzmu, aż do czwartego Soboru Ekumenicznego(451) ruch monastyczny rozwijał się w sposób spontaniczny, tzn. nie istniały ani ze strony Cerkwi ani państwa żadne normy kanoniczno-prawne, które określały by normy życia monastycznego. Było to powodem licznych nadużyć i skandali obyczajowych nie tylko w środowisku zakonnym. Sobór chalcedoński dokonał regulacji prawnych co się tyczy organizacji i funkcjonowania monasterów oraz oddał je pod dozór biskupowi die-

\footnotetext{
B. Doroszkiewicz, Monastycyzm Bizantyński od IX do połowy XV wieku, Białystok 2009 s. 38-39.
}

cezjalnemu. ${ }^{2} \mathrm{~W}$ myśl decyzji soboru chalcedońskiego, każdy klasztor musiał się podporządkować lokalnemu biskupowi, który wydawał pozwolenie w celu np. ufundowanie klasztoru, zatwierdzał projekt i wymagał załatwienia wszystkich związanych z tym formalności. ${ }^{3}$ Pomimo funkcjonowania monasteru w obrębie danej diecezji posiadał on pełnię autonomii i niezależności. Władze nadrzędne miały prawo interweniować jeśli dochodziło do skandali obyczajowych bądź pojawienia się herezji w obrębie wspólnoty. W okresie X-XII wieków klasztory powoli tracą swoją autonomię przechodząc $\mathrm{w}$ ściślejszą zależność od władz cerkiewnych a nawet osób prywatnych. Pojawiają się klasztory cesarskie, patriarsze biskupie a nawet zarząd nad

\footnotetext{
A. Znosko, Kanony Kościoła Prawosławnego, Wydawnictwo Bratczyk, Hajnówka 2000, s. 54.

3 B. Doroszkiewicz, Monastycyzm..., s. 301.
} 
klasztorami przejmują osoby świeckie,czyli tzw klasztory ktitorskie. ${ }^{4}$ Według statutu którym kierowały się monastery ktitorskie, pozwalano komuś kto dawał ziemię pod budowę monasteru, lub komuś kto finansował jego budowę na współudział w jego zarządzaniu. Ale nie było to do końca regułą bo czasami świeccy właściciele zrzekali się swoich praw i przekazywali swoją część władzy nad monasterem przeorom. Do tzw. monasterow ktitorskich należał serbski monaster Chilindar na świętej Górze Atos. Los sprawił, że prawa ktitorskie przeszły na wszystkich potomków serbskiej królewskiej rodziny Niemanjów. Członek rodziny, który tracił godność królewską tracił również prawa ktitorskie. Potwierdzenie klasztornych przywilejów oraz otrzymanie szczególnego monasterskiego immunitetu zależało nie tylko od ktitora monasteru ale również od cesarskiej chrysobulli, która zwalniała monaster od podatków. Taką chrysobullę otrzymał Chilindar w 1198-1199 od cesarza Aleksego III Angelosa. ${ }^{5}$ Co się tyczy nazewnictwa monasteru, to istnieje na ten temat kilka hipotez . Pierwsza głosi, że słowo Chilandar może pochodzić od chelandion - rodzaju statku bizantyjskiego. Druga natomiast konstatuje, że nazwa Chilendar nawiązuje do imienia założyciela pierwszej wspólnoty mniszej na tym miejscu. Inna z kolwji głosi, że Chilendar został on założony ponad sto lat wcześniej. Pewien Georgios Chelandarios (przewoźnik), wymieniony wśród ważnych Atonitów w 980 roku, założył monaster, który później został nazwany jego imieniem. Notatka o monasterze Chilindar w pierwszych serbskich źródłach przybiera formę Hilandaru. W greckich aktach nazwa Chilindar pojawia się w 1112 wieku. ${ }^{6} \mathrm{~W}$ aktach Protatonu z roku 1169 wśród sygnatariuszy dokumentu widnieje między innymi podpis ihumena Gerasima z Chelandaru. ${ }^{7} \mathrm{Na}$ jakiś czas monaster został opuszczony i podobnie jak wiele innych sąsiednich konwentów i kielii popadł w ruinę. Działo się tak dlatego, że bezbronne atoskie opactwa padały stawały się łatwym celem ataków ze strony różnego rodzaju korsarzy i rozbójników. Dopiero XII w. Chilendar zostaje odnowiony przez króla Serbów Stefana Nemanię, który zrezygnował z królewskiego tronu w Serbii, wstąpił do monasteru i przyjął imię Symeon, oraz jego syna Rastka, który przyjął imię zakonne Sawa. Rastko przybył na Atos w 1191 roku. Nie licząc się ze sprzeciwem swego ojca Stefana Nemanii, Rastko otrzymał w Russikonie mnisze postrzyżyny, po czym przeniósł się do greckiego monasteru Watopedi gdzie czekał na przybycie z Serbii swego ojca Stefana, który abdykując na rzecz swego drugiego syna Stefana I w $1196 \mathrm{r}$. wstąpił w do monasteru Studenica w Serbii i w dwa lata później bo w 1197 r. przybył na Atos już jako mnich wielkiej schemy o imieniu Symeon. Wraz z mnichem Sawą obaj rozpoczęli poszukiwanie miejsca zaakcentujące serbski charakter oraz pochodzenie obu dostojnych mnichów. Bi-

\footnotetext{
4 Tamże, s. 102-103.

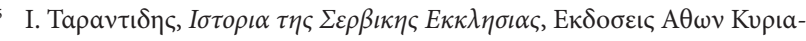

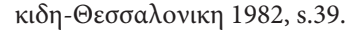

6 N. Begovic, Istoria Srpske Crkve, Novi Sad 1877. С. Кадас, Святая Гора Афон, Издателство: EKDOTIKE ATHENON, Афины 2009, s. 57.

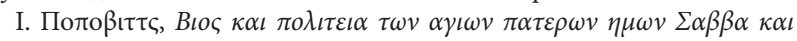
$\Sigma v \mu \varepsilon \omega v$, A 7 vo 1975, s. 18. D. Medakovic, Chilandar, Beograd 1978, s. 126.
}

zantyński cesarz Aleksy III Angelos, którego córka poślubila brata Sawy, Stefana I w 1198-1199 roku odstąpił Chilandar na wieczne użytkowanie swoim nowym serbskim krewnym. Porzucony mały monaster Chilindar, który spod zarządu Protatonu przeszedł pod jurysdykcję monasteru Watopedi wymagał natychmiastowej odbudowy. Na potwierdzenie darowizny Sawa otrzymał od cesarza Aleksego III Angelosa złotem opieczętowany sigillion. ${ }^{8}$ Cesarski sigilion był wydany wraz z potwierdzającymi jego autentyczność dokumentami określającymi granice monasterskich nieruchomości. Ponieważ nieruchomości nadane dla nowego serbskiego monasteru uszczupliły trochę terytoria należące do monasteru Watopedi, toteż ten ostatni zaczął rościć pretensje terytorialne. Sawa wraz z Symeonem odwołali sie natychmiast do cesarza Aleksego w Konstantynopolu, który potwierdził swoją wcześniejszą decyzję darowizny jak również nadał klasztorowi podobny statut niezależności jaki przedtem nadał gruzińskiemu klasztorowi Iwiron (klasztor gruziński) i Amalfici (klasztor włoski). ${ }^{9}$ Cesarz Aleksy wyraził zgodę i potwierdzil chryzobullą z czerwca 1198 roku oddając Chilandar wraz ze wszystkimi świętymi miejscami w Milees pod władzę i zarządzaniem Symeona i Sawa jako klasztor całkowicie samorządny, aby „był on darem dla Serbów na wieczność. ${ }^{10} \mathrm{~W}$ drugiej połowie 1198 roku Symeon Nemanja wydał Chilandarowi opieczętowaną złotą pieczęcią kartę ustanawiając go serbskim monasterem, dziedziczonym przez rodzinę Nemanjów. Stworzono rdzeń majątku ziemskiego Chilandaru: Chilandar otrzymał chłopów pańszczyźnianych z dziewięciu wsi $\mathrm{z}$ regionu Prizren, na Kosowie, dwie winnice, cztery hodowle pszczół, jedną górę i 170 wołoskich pasterzy, wraz z pewnymi oddzielnymi darami z bydła i soli. $\mathrm{W}$ chwili śmierci Symeona 13 lutego 1199 roku Chilendar nie był jeszcze zupełnie ukończony. Prawdopodobnie była już ukończona cerkiew gdyż Symeon po śmierci w został w jej narteksie pochowany. ${ }^{11}$ Wiosną 1200 roku Sawa ponownie udał się on do Konstantynopola i uzyskał (w czerwcu) od cesarza Aleksego inny opieczętowany złotą pieczęcią sigilion, który oddawał Chilandarowi na użytkowanie stary, opuszczony klasztor Zygos (obecnie w ruinach, na zachodnim stoku Megale Vigla) i prawo posiadania łodzi o długości 1000 jednostek, jak również potwierdzający wszystkie przywileje i prawa nadane bullą z 1198 roku. Początkowo Chilandar nie wliczając Symeona i Sawy, włącznie z pierwszym ihumenem Metodym, (Metodije), który odwiedził w 1198 r. Serbię, składał się tylko z15 mnichów, ale sześć lat później w klasztorze było 90 serbskich mnichów. Po śmierci św. Symeona i ukończeniu monasteru św. Sawa, zgodnie $\mathrm{z}$ duchem prologu typikonu konstantynopolitańskiego monasteru „Ewergetis,” napisał swój „Typikon”, który nadal jest zachowany na oryginalnym zwoju pergaminu w Chilandarze. Tekst tego typikonu został również wyryty nad główny-

\footnotetext{
8 D. Dasic, Sveti Sava, Spomenica, Beograd 1969, s. 112.

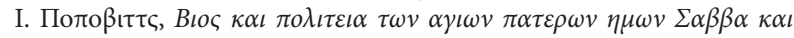
$\Sigma v \mu \varepsilon \omega v$, A $\theta \eta v a$ 1937, s. 66.

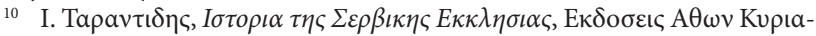
$\kappa \iota \delta \eta-\Theta \varepsilon \sigma \sigma \alpha \lambda$ ovıкๆ, 1982, s. 31.

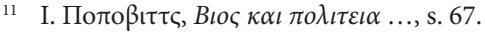


mi drzwiami cerkwi w pustelni Karies, która z tego powodu była później nazywana Typikarnicą. ${ }^{12}$ Chilandar został więc zorganizowany według wzorców monastycyzmu greckiego, wedle którego mnisi stanowili ściśle zespoloną wspólnotę, pracującą i modlącą się razem pod rządami ihumena. ${ }^{13}$ Priorytet nadano pracy duchowej tzn. mnisi pod duchową opieką przełożonego, powinni regularnie spowiadać się i trzy razy w tygodniu, przystępować do komunii. ${ }^{14}$ Pierwszy rozdział typikonu, po wstępie i informacji dotyczącej założenia klasztoru, z notatką na temat śmierci świętego Symeona, poświęcony jest określaniu różnych form kultu. Zasady dotyczące wspólnych posiłków bardziej wiązały się z duchowym pożytkiem niż z dyscypliną podczas posiłków, choć i na to także zwracano uwagę. Z koleji Chilendar był wolny zarówno od Protatonu, jak i od władzy cesarskiej co odzwierciedlało się się całkowitej suwerenności klasztoru w zakresie wyboru ihumena. (rozdziały 12 i 13). Należy zwrócić uwagę na to, że nawet Wielka Ławra nie miała takiego przywileju. W Chilendarze władza cesarska była reprezentowana tylko symbolicznie w osobie ihumena. Ihumen był wybierany przez uprawnione grono wyborcze składające się z ekonoma lub intendenta, eklezjarchy i 10-12 starszych mnichów. Same wybory odbywały się w głownym katolikonie - cerkwi, gdzie następnie nowo wybrany ihumen był wprowadzany na specjalnie przygotowany tron. Po ihumenie najważniejszą funkcję monasterską pełnił ekonom, potencjalny następca ihumena. Wyznaczano mu też dwóch pomocników: parekonoma i ekonoma zewnętrznego. Kolejną ważną funkcją w klasztorze sprawował eklezjarcha, którego obowiązkiem była piecza nad cerkwią i nabożeństwami, zazwyczaj z pomocą pareklezjarchy. Docheiares odpowiadał za sprawy finansowe monasteru. Typikon określa również inne obowiązki: mnisi odpowiadający za refektarz, klucze, pieczenie chleba, łowienie ryb i muły. Wymagano przykładowego porządku i posłuszeństwa we wszystkim, tak by uwzględniane były najważniejsze duchowe cele życia we wspólnocie monastycznej bowiem „Pobożność, miłość i jedność” są ważniejsze niż liczby, jako że „lepiej, by był tylko jeden, który wypełnia Bożą wolę niż mnóstwo bezprawnych" (rozdział 25). ${ }^{15} \mathrm{Ty}-$ pikon nie zapomina i o działalności charytatywnej typu tej, którą bardzo często praktykowano w klasztorach Konstantynopola. Obok klasztoru pobudowano dom dla gości (xenodocheion) celem przyjmowania mnichów pochodzących z obcych krajów i chorych, podczas gdy wewnątrz samego klasztoru wydzielono salę jako infirmerię [izbę chorych] - pierwszą serbską instytucję tego rodzaju - z łóżkami dla ciężko chorych mnichów i bratem, którego obowiązkiem było opiekowanie się chorymi. Szpital później rozszerzono i przydzielono dla niego oddzielny intratę i darmowe wyposażenie (karta praw Duszana i Lazara). W leczeniu stosowano najnowsze metody zachodnioeuropejskie, oparte na klasycznych tradycjach Hipokratesa, Ga-

12 К. Г. Nıх

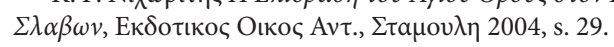

13 B. Doroszkiewicz, Monastycyzm...s. 61.

14 D. Medakovic, Chilandar, Beograd 1978, s. 134.

15 D. Medakovic, Chilandar..., s. 134. lena, Dioskoryda i innych (Chilandar posiada ważne manuskrypty z tekstami medycznymi z końca XIV i połowy

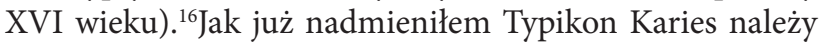
do tak zwanych reguł „skitu” (anachoretycznych), kiedy to dwóch lub trzech pustelników odmawia psałterz "godzinami” w dzień i w nocy, ze ścisłym postem i wszelkiego rodzaju wstrzemięźliwością. Podobny rygor prawdopodobnie został wprowadzony w innej celi Chilandaru i wieżach, zbudowanych w XIII i XIV wieku. Pragnąc większego odosobnienia i zachowania nastroju hezychazmu, Sawa już w 1199 roku założył w Karies pustelnię - celę pod wezwaniem jego patrona, świętego Sawy Jerozolimskiego. Po śmierci Symeona w 1200 r. Swa powrócił do Serbii w celu organizowania Kościoła Prawosławnego a w 1219 r. został on pierwszym arcybiskupem Serbskiego Autokefalicznego Kościoła Prawosławnego. Przed rokiem 1262 serbski król Urosz I zbudował wielką Wieżę Przemienienia Pańskiego w odległości pół godziny marszu w górę od monasteru w kierunku południowym (obecnie Spasowa Woda). W niej to mnich Domecjan napisał życie św. Symeona. Była to jego druga praca po życiu św. Sawy,które napisał dwie dekady wcześniej w Karyes w 1243r. ${ }^{17}$ W 1303 roku król Milutin zbudował na gruzach starego,nowy kościół, wzniósł zewnętrzne obwarowania pobudował obok portu Chilandaru tzw. Wieżę św. Bazylego, (Hrusja), nadając jej status niezależnej celi. Jasne jest, że wieża i cela zostały zbudowane $\mathrm{w}$ miejscach zarówno ważnych strategicznie, jak i dla praktykowania życia duchowego i pracy intelektualnej w kompletnej cichości: pustelnia Karies, Hrusija i Wieża Przemienienia Pańskiego. W 1321 r. centralna świątynia monasteru,refektarz oraz kaplica cmentarna zostały ozdobione freskami. Podstawą ekonomiczną egzystencji Chilandaru w średniowieczu był jego majątek ziemski. Od dziewięciu wsi i innych darów z regionu Prizren nadanych monasterowi na mocy założycielskiej karty praw Stefana Nemanji w 1198 roku, w ciągu XIII i XIV wieku majątek ziemski powiększył się o dość duże obszary w centralnej Serbii, jak również o liczne nieruchomości od „Tesalonik aż do na północ”18 $\mathrm{Na}$ początku XV wieku Chilandar posiadał ponad 30 metochionów z 360 wsiami,. Przed połową XIV wieku Chilandar sam posiadał niemal piątą część półwyspu Atos, co równa się około $60 \mathrm{~km}^{2}$. Bogate archiwa monasteru Chilandar,umożliwiają stosunkowo dokładne odtworzenie historii monasteru w XIII i XIV wieku i wzrost jego ważności duchowej, ekonomicznej i politycznej. Szczególnie wybitną rolę w historii Chilandaru, odegrali ihumeni; byli wybierani za wcześniejszą aprobatą serbskiego władcy. Pierwszym wybitnym ihumenem był Metody, wyznaczony przez samego św. Symeona,który pomógł Sawie odbudować i ukończyć monaster. Był on aktywnym uczestnikiem założenia Serbskiej Cerkwi Prawosławnej. Na zaproszenie swego brata Stefana w 1206 roku Sawa przeniósł relikwie swego ojca św. Symeona do Serbii i pozostał tam jako archimandryta monasteru Studenica. Jedenaście lat później

\footnotetext{
16 Tamże, s. 139.

17 D. Medakovic, Chilandar..., s. 142.

18 D. Medakovic, Chilandar..., s. 145.
} 
w 1217 powrócił on na Atos i zajął się uzyskaniem praw do niezależnego, autokefalicznego arcybiskupstwa dla Serbii. Osiągnął to w Nicei w 1219 roku. Wracając do Serbii drogą wiodącą przez Chilandar, przywiózł on nie tylko księgi, w oparciu o które zbudował on później organizację nowej Cerkwi i państwa (Kormczaja-Kodeks), ale też ludzi, którzy mieli służyć jako biskupi i pomóc mu w realizacji jego planów. Jednym z nich był prawdopodobnie Metody, który miał zostać biskupem Rascii (tj. Serbii). Święty Sawa udał się tylko raz jeszcze na Świętą Górę, po powrocie ze swej pierwszej pielgrzymki do Świętej Ziemi w 1230 roku, ale nie wiemy, kto był wtedy ihumenem Chilandaru. ${ }^{19}$ Trzeci serbski arcybiskup, Sawa II, najmłodszy syn króla Stefana Prwowenczani (Stefana Pierwszego Ukoronowanego), Predisław, także był mnichem na Górze Atos. Chilandar zyskiwał coraz większy prestiż i poszerzał swe posiadłości (karty praw cesarza bizantyjskiego Jana Dukasa Watatsesa i Michała III Paleologa oraz serbskich królów Władysława, Urosza I i Dragutina)..$^{20}$ Ale największym dobroczyńcą był król Milutin (1282-1321), który znacznie powiększył potęgę ekonomiczną i polityczną serbskiego państwa i dokonał pierwszego poważnego wtargnięcia na terytorium Bizancjum od strony Macedonii. W tym samym czasie podniósł on reputację Chilandaru i jego znaczenie religijno-polityczne. Pod koniec XIII wieku stan liczebny monasteru znacznie wzrósł, ale klasztor nieustannie był zagrożony atakami piratów i lokalną anarchią. Milutin zbudował nową cerkiew na fundamentach starej w 1293 roku oraz wzmocnił i powiększył istniejące fortyfikacje. Nowymi budynkami były wieża -Hrusija przy porcie i budowla znana jako Wieża Milutina przy wejściu od Pola Sawy do wąskiej doliny strumienia Chilandaru, obok ścieżki prowadzącej do monasteru. Oba donżony zostały zbudowane w 1302 roku i obsadzone przez strażników z Prizren. Ich znaczenie oceniono wkrótce potem, w 1307 roku, kiedy to katalońscy piraci zaatakowali Chilandar. W czasie tych wydarzeń Daniel (Daniło), ihumen monasteru od 1306 roku, kierował jego obroną i wykazał się wyjątkową odwagą i zdolnościami wojskowymi. Ihumen Daniło zaznajomiony z wielkimi greckimi myślicielami, teologami i cerkiewnymi dostojnikami, którzy żyli na lub odwiedzili Atos w pierwszych dziesięcioleciach XIV wieku, wiele uczynit, aby zapewnić trwałe i dogłębne zakorzenienie się bizantyjskiego wpływu na średniowieczną Serbię. Jego następca, Nikodem był ihumenem $w$ Chilandarze $w$ latach 1312-1316 i arcybiskupem w latach 1317-1324. Udał się w 1313 roku do Konstantynopola z misją dyplomatyczną i uzyskał dwie chryzobulle z kolejnymi nadaniami terytorialnymi od cesarza Andronika II. Podczas jego przebywania została odbudowana i umocniona cela Karies (1312) w której Nikodem spędził jakiś czas jako zwykły mnich. Wyjątkową postacią w historii Chilandaru w XIV wieku był niewątpliwie ihumen Gerwazy (1317-1336). Gerwazy (Gerwasije) objął kierownictwo nad Chilandarem w czasie dynamicznego rozwoju stosunków pomiędzy Bizancjum a Serbią. Służył on jako

\footnotetext{
19 Tamże, s. 146.

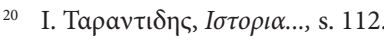

dyplomata nie tylko Milutinowi, ale też Stefanowi Duszańskiemu, a nawet królowi Duszanowi. Uczestniczył w pracach Serbskiego Zgromadzenia Narodowego, uczestniczył w redagowaniu ogromnej liczby cesarskich i królewskich ustaw: ze 146 greckich ustaw odnoszących się do Chilandaru z XIV wieku 95 pochodzi z okresu, kiedy ihumenem by Gerwazy.

Po śmierci Gerwazego nastąpił okres panowania króla, Duszana (1331-1355), który przyłączył do swego państwa znaczne terytoria cesarstwa bizantyjskiego, włącznie $\mathrm{z}$ terytorium Świętej Góry. W tym czasię następcą Gerwazego został Arseniusz (1336-1345). Duszan doprowadził Chilandar do jego szczytowej formy w całej jego średniowiecznej historii. Jego dziesięć kart praw dostarczyło klasztorowi większość jego własności ziemskiej. Na samym Atosie zgrupował on dzierżawy monasteru (1347-1348), wykazując wielką hojność wobec innych klasztorów. Król Duszan(1331-1355) znalazł azyl w Chilandarze przed panująca na Bałkanach dżumą. Korzystając ze szczedrości serbskich władców Chilandar wkrótce został właścicielem wielkich posiadłości ziemskich, włącznie z kilkoma terenami na Chalkidiki koło Salonik. Tak więc jedna - piąta Atosu stała się własnością Chilandaru. ${ }^{21}$

W drugiej połowie XIV wieku miała miejsce szybka rotacja ihumenów; byli nimi: Kalinnik, Teodul (starzec celi Karies), Sawa (późniejszy serbski patriarcha Sawa IV, 1354-1375), po czym Jan, Doroteusz i, w krótkich okresach, Teodozjusz, Kalikst, Jan, Eutymiusz, Neofit i inni. Najważniejszym z nich był Doroteusz (Dorotej, 1355-1361), który nieustępliwie bronił praw Chilandaru i dążył do przywrócenia mu jego dawnych przywilejów. W siódmym dziesięcioleciu XIV wieku Doroteusz został protosem Świętej Góry, a pełniąc tę funkcję uczynił wiele, by przynieść korzyść serbskiemu monastycyzmowi na Atosie pomimo schizmy religijnej, która pojawiła się, kiedy konstantynopolitański patriarcha Kalikst ekskomunikował Serbów w 1350 roku po bezprawnym podniesieniu przez Duszana Serbskiej Cerkwi do rangi patriarchatu. Chilandarski mnich i Serb, starzec Izajasz, służył jako pośrednik, wraz ze swymi uczniami Nikandrem i Sylwestrem oraz z byłym protosem Teofanesem i Nikodemem Grekiem, pomiędzy Cerkwią Serbską a patriarchą Konstantynopola (1375). Dążyli oni do zniesienia ekskomuniki, przywrócenia jedności kościelnej i uzyskanie uznania autokefalicznego patriarchatu serbskiego. ${ }^{22}$ Była to ostatnia, ale najważniejsza i udana misja dyplomatyczna podjęta przez atoskich Serbów w stosunkach pomiędzy Serbią i Bizancjum przed upadkiem niezależnego państwa serbskiego.

Pod koniec XIV wieku, a zwłaszcza na początku wieku XV, kiedy to ziemiami serbskimi rządzili książęta i despoci/ despotinowie, majątki ziemskie Chilandaru nadal się powiększały, jak wykazują to liczne karty praw wydane przez serbskich władców tego okresu. Despot Jovan Ugliesa przed swoja śmiercią podczas bitwy z Turkami nad rzeką Maricą

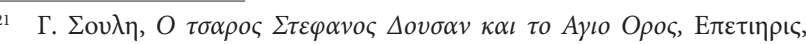
Agion Oros, s. 77.

${ }^{22} \Gamma . \Sigma o u \lambda \eta \mathrm{O} \sigma \sigma \alpha \rho \circ \varsigma \Sigma \tau \varepsilon \varphi \alpha v o \varsigma \Delta o v \sigma \alpha v$..., s. 79.
} 
w 1371 r. podarował dla monasteru część swych włości. Natomiast Toma Preljubovic, serbski zarzadca Albanii i Epiruza fundowali malowanie fresków w kościele św. Archanioła. Przed bitwą pod Kosowem serbski książę Lazar Hrebeljanovic(1371-1389), kazał w 1380 r. dobudować narteks do wschodniej części głównej cerkwi Matki Boskiej. Narteks Lazara nadał centralnej świątyni budowanej od czasów króla od czasów Milutina ostateczny wygląd. W roku 1379 podarował on infirmerii klasztoru wieś Jelasznica w rejonie Hwosno. Chryzobulla Lazara dokumentująca to nadanie, zatwierdzona i podpisana przez patriarchę Spirydona przechowywana jest w Chilandarze. Jednakże bitwa na Kosowie przerwała związki Chilandaru z Serbią, nie tylko z powodu podboju Turków, ale też z powodu zaistniałych konfliktów pomiędzy rodzinami Brankowiczów i Lazarewiczów którzy przed tym również pomagali innym atoskim klasztorom aż do ostatecznej klęski Serbii w 1459 roku. ${ }^{23}$ Tak oto atoskie klasztory, a zwłaszcza Chilandar, służyły jako miejsce schronienia dla ostatnich serbskich domów panujących i szlachty. Niewidomy Grgur Brankowicz, syn despotina Djuradji Brankowicza, zmarł 16 października 1459 roku jako mnich German w metochionie Chilandaru w rejonie Strumy (Strymon) i został pochowany w Chilandarze. W Chilandarze znaleźli prawdopodobnie schronienie również niektórzy dygnitarze kościelni, pozbawieni przez wojnę swoich eparchii lub monasterów. Wiemy z pewnością, że tak stało się w przypadku metropolity Serraju (Sirrhae), Sawy (1381-1386) i metropolity Melnika Cyryla. ${ }^{24}$

Tureckie podboje natychmiast po bitwie pod Maritsą, potem pierwsza okupacja Atosu, po 1430 roku spowodowały wielki niepokój wśród mnichów Świętej Góry, a nawet eksodus. Podczas gdy wcześniejsi władcy, panowie feudalni i wysocy dygnitarze kościelni szukali schronienia na Atosie, wielu mnichów uciekło na północ. Przed upadkiem despotatu ta fala emigrantów ze Świętej Góry dotarła do serbskiego państwa w dolinie Morawy. Ciekawe szczegóły zawarto w Żywocie Romilusa z Rawanicy. W całym regionie panowała przemoc i bezprawie. Pomimo specjalnego firmana (dekretu) wydanego przez sułtana Mehmeda II w 1457 roku, potwierdzającego dawne swobody monasterów Świętej Góry, mnisi Atosu podzielili los prawosławnych mnichów we wszystkich ziemiach Bałkan znajdujących się pod panowaniem Turków.

Szukając wsparcia oraz pomocy materialnej mnisi z Chilandaru sami udali się do Rosji. W 1550 roku ihumen Paisjusz z trzema starcami odwiedził Moskwę, by prosić Iwana IV Wasiljewicza (Iwana Groźnego) o pomoc i obronę. Rosyjski car interweniował u sułtana, prosząc o ulgi dla Chilandaru. Zezwolił on również na kolektę datków na Rusi, a i sam posłał bogate dary dla monasteru (1556) oraz darował Chilandarowi rezydencję w Moskwie. ${ }^{25}$

Pomimo licznych trudności w Chilendarze 1560 roku było w nim 200 mnichów, którzy zachowywali status zgromadzenia cenobitycznego. W wieku XVII, złotymi litera-

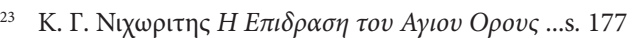

24 D. Medakovic Chilandar...s. 151

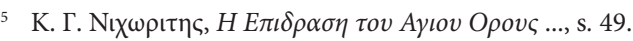

mi zapisał się ihumen Wiktor (ok. 1652-1678), ze względu na prowadzone na szeroką skalę pracami budowniczymi. W tym okresie w odbudowie i rekonstrukcji monasteru wielką pomoc okazał klasztoru odegrał ihumen Symeon, serbski kupiec mieszkający w Wenecji, który później mieszkał na Świętej Górze, a począwszy od roku 1662 jako mnich Nikanor w jednej z cel Św. Pawła (celi Zbawiciela). Splacił długi monasteru zbudował cerkiew pod wezwaniem Świętej Trójcy, naprawił stare cele i obdarzył darami cerkwie Przemienienia Pańskiego i Św. Sawy. I ofiarował monasterskiej bibliotece dużą liczbę drogocennych ksiąg. Został przez historię nazwany drugim założycielem Chilandaru. ${ }^{26}$ Jeśli wierzyć Josifowi Georgirenisowi, arcybiskupowi Samos, którego książkę na temat Atosu wydano w języku angielskim w Londynie w 1678 roku, w tamtym czasie serbski monaster miał największą liczbę mnichów: aż do 800. Nawet jeśli była to liczba przesadzona albo dokonano błędnych obliczeń w oparciu o fizyczne zobowiązania monasteru, widać wyraźnie, że hojność starca Nikanora pomogła klasztorowi przezwyciężyć jeden z jego najgłębszych kryzysów.

Ważnym źródłem dochodu w XVI i XVII wieku i później były datki od pobożnych chrześcijan z całych Bałkan zbierane przez chilandarskich mnichów. Monaster zachował księgi zawierające imiona ofiarodawców,które były wymieniane i wspominane podczas nabożeństw. Najstarsza księga tego rodzaju pochodzi z XVI wieku. Obok imienia ofiarodawcy zapisywano datę i miejsce, umożliwiając w ten sposób odtworzenie regionów, w których Chilandar wywierał swoje wpływy.

Kolekty i zapisywanie datków nie oznaczały „żebrania” (jak mylnie sądzono przez dłuższy czas). Najbardziej znakomici chilandarscy mnisi wyruszali na tę misję, niosąc ze sobą nie tylko ewangelie i tym podobne księgi dla potrzeb liturgicznych, ale także żywoty serbskich władców i arcybiskupów, które czytali oni ofiarodawcom, a przez to podtrzymywali znajomość historii. Podczas gdy w średniowieczu Chilandar był rzeczywiście przedstawicielem legalnej serbskiej narodowości na obcej ziemi - terytorium Bizancjum, to w okresie tureckiej okupacji wszyscy Serbowie traktowali monaster jako niezniszczalny dowód ich wcześniejszego wolnego życia, ich Cerkwi i kultury. Z drugiej strony, Serbscy patriarchowie, biskupi i kler nadal pomagali Chilandarowi. Wiele ksiąg i przedmiotów sakralnych w monasterze świadczy o trosce o Chilandar okazywanej przez serbski patriarchat w Peczu. Kroniki Zonara z trzeciego dziesięciolecia XVI wieku, wcześniej znajdujące się w posiadaniu metropolity Prizren, Michała (Michaiło), dotarły do Chilandaru jako dar od patriarchy Jana (Jowana) z Peczu po śmierci metropolity w roku 1602. Silny związek Hilindaru z narodem serbskim utrzymał się do XVII-XVIII w., gdy liczba przybywających na Athos Serbów spadła, następnie zaś w 1722 Chilandar został zniszczony przez pożar. Monaster przetrwał dzięki działalności mnichów bułgarskich. Po odzyskaniu przez Serbię niepodległości (1830) Chilendar pomimo faktu, że

26 D. Medakovic, Chilandar..., s. 153. 
był w większości zamieszkany przez bułgarskich mnichów cieszył się materialnym wsparciem ze strony serbskiego księcia Milosa Obrenovica. Spory odnośnie administrowania monasteru zostały wygaszone przez wizytującego w 1896 r. króla Serbii Aleksandra Obrenovica, który spłacił monasterskie długi. Bułgarscy mnisi przenieśli się do Zografu natomiast z Serbii do Chilindaru zaczęli napływać serbscy mnisi. ${ }^{27}$ Kolejny pożar zniszczył zabudowa-

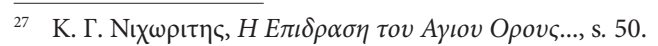

nia klasztoru w 1891. Chilandar jest przykładem nie tylko silnych związków z Serbią ale również Serbii z Atosem w całym. Pomimo faktu, że Hilendar kieruje się do dnia dzisiejszego typikonem św. Sawy a nie Tsimiskesa,jak inne atoskie monastery jego relacje $\mathrm{z}$ macierzą I sąsiadami nawet $\mathrm{w}$ najtrudniejszych momentach osmanskiej niewoli były wzorcowe. Do dnia dzisiejszego funkcjonuje wyrażenie oddające klimat tych relacji,że monaster Hilendar jest sercem Serbii. Tak długo puki będzie bić serce, to będzie funkcjonować ojczyzna Serbów.

\section{Bibliografia}

Begovic N., Istoria Srpske Crkve, Novi Sad 1977.

Doroszkiewicz B., Monastycyzm Bizantyński od IX do połowy XV wieku, Białystok 2009.

Dasic D., Sveti Sava,Spomenica, Beograd 1969.

Medakovic D., Chilandar, Beograd 1978.

Znosko A., Kanony Kościoła Prawosławnego, Wydawnictwo Bratczyk, Hajnówka 2000.

Кадас С., Святая Гора Афон, Издателство: EKDOTIKE ATHENON, Афины 2009.

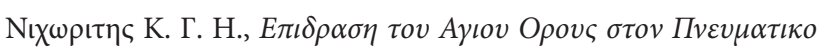

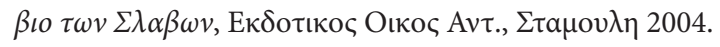

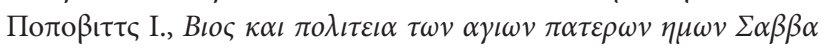
$\kappa \alpha \iota \Sigma v \mu \varepsilon \omega v$, A $\theta \eta v \alpha 1975$.

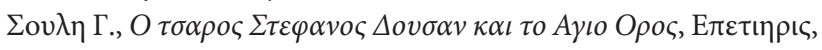
Agion Oros 1965.

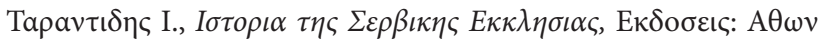

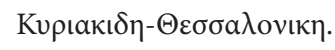

Rozmiar artykułu: 0,8 arkusza wydawniczego 
ISSN 1508-7719

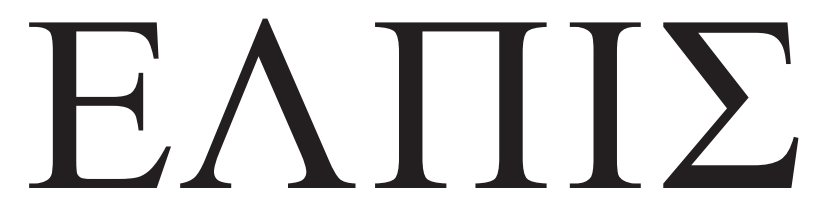

CZASOPISMO TEOLOGICZNE KATEDRY TEOLOGII PRAWOSŁAWNEJ UNIWERSYTETU W BIAŁYMSTOKU

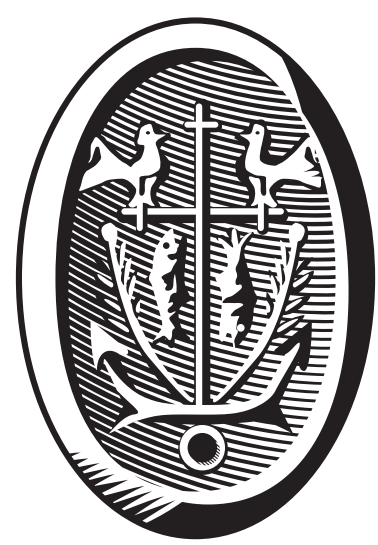

ADRES REDAKCJI

15-097 Białystok, ul. M. Skłodowskiej-Curie 14 tel. 85 745-77-80, e-mail: redakcja@elpis.edu.pl www.elpis.uwb.edu.pl 